\title{
The Status Quo and Reform Thinking of the Talent Training Mode of Biology Teachers in Middle School
}

\author{
Bo Peng ${ }^{1}$, Chuanling Zhang ${ }^{1}$, Feng Peng ${ }^{2}$, Xuezhong Sun $^{3}$, Xiayu Tian ${ }^{1}$, Xiaorui Ma ${ }^{1}$, Ruihua Pang ${ }^{1}$, Yanfang \\ Sun $^{1}$, Wei Zhou ${ }^{1} \&$ Quanxiu Wang ${ }^{1}$ \\ ${ }^{1}$ College of Life Sciences, Xinyang Normal University, Xinyang, Henan, China \\ ${ }^{2}$ Biology Teaching Group, Gushi No. 1 Middle School, Gushi County, Henan, China \\ ${ }^{3}$ Henan XinYang Senior High School, Xinyang, Xinyang, Henan, China \\ Correspondence: Bo Peng, College of Life Sciences, Xinyang Normal University, Xinyang, Henan 464000, \\ China. E-mail: pengbo@xynu.edu.cn
}

Received: September 13, 2020 Accepted: November 3, 2020 Online Published: November 12, 2020

doi:10.5539/jel.v9n6p84 URL: https://doi.org/10.5539/jel.v9n6p84

\begin{abstract}
It has always been one of the hot spots of the whole society to improve teachers' quality and ability. With the progress of the era and the rapid development of biology, it puts forward higher requirements for the cultivation of biology teachers of middle school. How to cultivate a large number of high-quality biology teachers of middle school with good ethics and outstanding abilities is a focus problem worth exploring. There are some problems in the traditional training mode of biology normal students, such as backward teaching idea, unreasonable teaching arrangement and uneven teaching level. In view of these problems, normal universities should take a series of reform measures to promote the professional development of middle school biology teachers. Therefore, this paper summarizes the reform necessity, current situation and existing problems of the talent training mode. It also puts forward a series of reform measures on the talent training mode in the aspects of learning, innovation and reflection. Thus, this paper will provide important reference for the reform of talent training mode of middle school biology teachers in the future.
\end{abstract}

Keywords: biology teacher, teacher training, training mode, reform

As the saying goes, if a country wants to prosper, it must value the teachers. Education is related to the prospects of the Chinese nation in the future, while the middle school teachers who take "preaching, teaching and dispelling doubts" as their duty play an important role in cultivating the pillars of society and developing educational business. As an important compulsory course in middle school, biology needs excellent teachers to stimulate students to love life and care about society while imparting knowledge, so as to cultivate their essential biological core literacy. Therefore, in the reform of the training mode of middle school biology teachers, we should not only pay attention to teachers' knowledge and teaching skills, but also strengthen the construction of teachers' quality and ethics, which is the only way to cultivate middle school biology teachers with the spirit of the new era.

\section{The Necessity of Reforming the Training Mode of Middle School Biology Teachers}

Education reform is a hot research topic, so is the reform of the training mode of middle school teachers. First of all, it is very important to know why to reform. It is necessary to reform and gradually improve the training mode of middle school biology teachers, which is not only the requirement of the new era, but also the inevitable demand for the development of biology subject and teachers.

\subsection{The Training Mode Reform of Middle School Biology Teachers is the Requirement of the New Era}

The impact of education plan is far-reaching. With the rapid development of information technology, the international competition is becoming increasingly fierce and the demand for high-quality talents is particularly urgent. Many international organizations are reforming their talent training strategies in order to obtain long-term development advantages (Zeng, 2019). At the national education conference, President Xi proposed that we should speed up the modernization of education, build a powerful country in education and run the education to make people satisfied. Consequently, it is necessary for middle school biology teachers to help students establish a good outlook on life and nature in order to cultivate socialist builders and successors with all-round 
development of morality, intelligence, physique, beauty and labor. In the new era, the concept of middle school education is updating, and the talent training mode of biology normal students also needs to be reformed. Therefore, it is an inevitable requirement of the new era to improve their overall level and cultivate high-quality biology teachers under the guidance of the fundamental task of "cultivating people by virtue".

\subsection{The Development of Biology Discipline Requires to Reform the Training Mode of Biology Teachers of Middle School}

Biology is closely related to information and engineering technology, which has a great impact on many aspects of social life such as medical health, environmental protection and animal husbandry. Facing the new requirements of improving the national quality in the new era, the biology curriculum standard of middle school was revised in 2020 on the basis of the experimental version in 2017, which inherited and developed the content system for nearly ten years, and emphasized to implement the core literacy of biology. It is beneficial for middle school students to cultivate their life concept, scientific thinking, scientific inquiry and social responsibility (Ministry of Education, 2020). The reform of curriculum standards and the updating of biology teaching materials have put forward new requirements for teachers' teaching ability, which requires the normal colleges to reform the training mode of biology normal students and implement the requirements of developing biological core literacy.

\subsection{The Reform of the Training Mode of Biology Teachers of Middle School Needs a Standardized Teaching Team}

President Xi places great expectations on teachers, hoping that they could achieve the goal of teaching and educating people (Han et al., 2020). If teenagers want to buckle well the first button in their lives, middle school teachers are the "buttoners". If teenagers want to realize the Chinese dream of the great rejuvenation of the Chinese nation, middle school teachers are the "dream builders". Teachers' words and deeds have a profound impact on middle school students' study and life. The demonstration of teachers' work requires to enhance the standardization of teachers' training. In order to cultivate the biological core literacy of middle school students imperceptibly, it is necessary to improve the training mode of middle school biology teachers and build a high-quality modern middle school teachers' team. Only with high-level biology teachers can we have high-quality biological science education in secondary schools.

\section{Current Situation of Middle School Biology Teachers' Training}

The training quality of biology teachers of middle school is related to the improvement and development of biology education quality. Many countries are actively seeking for new modes for training middle school biology teachers, which will lay a good foundation for students who may enter biology-related industries in the future. The improvement of talents training quality will enhance the national cultural soft power, so as to gain significant advantages in the long-term international competition. The following is a brief introduction to the current situations and future development trends of the cultivation of middle school biology teachers at home and abroad.

\subsection{The Present Situation of Middle School Biology Teachers' Training Mode in China}

The development course of middle school biology teachers' training in China is quite tortuous. Our biology curriculum was first introduced from abroad after the Opium War. In 1902, the Qing Government stipulated that biology students in normal colleges should learn pedagogical knowledge including "biology teaching method". After more than one century's practice and development, China has formed a relatively standard curriculum system of "Biology teaching theory", and vigorously cultivated biology normal students (Cui et al., 2016). After entering the 21 st century, the cultivation mode of middle school biology teachers has become more institutionalized and specialized. In 2011, The Teacher Education Curriculum Standards (Trial) vigorously promoted the reform and innovate the curriculum concept of teacher education, so as to cultivate high-quality and professional teacher talents. The biology curriculum structure of normal colleges follows the growth law of normal students. In the continuous of study and practice of different types of courses as shown in Table 1, normal students can gradually grow into qualified middle school biology teachers.

With the development of the era, the Ministry of Education has launched a series of plans on training "outstanding teachers". There are higher requirements for the cultivation of biology normal students, so that they can forge ahead towards the goal of "being great teachers" and strive to become the teachers with ideals and beliefs, moral sentiment, solid knowledge and benevolence! Only when middle school biology teachers teach well, can students have a good biological foundation. Only when industries like medicine, agronomy, scientific research have good talent reserves, can our country have inexhaustible development power. Under the strong 
policy guidance of the government, the main part advantages of normal universities and the active cooperation of secondary schools, China has formed a diversified, open and high-quality collaborative training system for middle school biology teachers (Li et al., 2020).

Table 1. The structure of training courses for normal biology students

\begin{tabular}{lll}
\hline Course type & Curriculum & Course function \\
\hline Public basic courses & Political courses, computer courses, English courses, & Cultivating ideological and cultural quality \\
& etc. & \\
Biology professional courses & Zoology, biochemistry, physiology, biostatistics, etc. & Deepening Biological knowledge \\
Education and teaching courses & Pedagogy, psychology, biology teaching theory, etc. & Learning biology teaching knowledge and skills \\
Practical courses & Biological practice, educational probation, & Training the teaching ability in middle school \\
& educational practice, etc. & biology class \\
\hline
\end{tabular}

As for the research on the cultivation of biology teachers in middle schools, experts and scholars have more and more researches and explorations on the teacher training mode and published a lot of literature with the state's standardization of the teacher training system. Searching with "teacher training" as the key word in CNKI, there were 3681 articles in total by October 2020. The statistics on the number of articles published are shown in Figure 1.

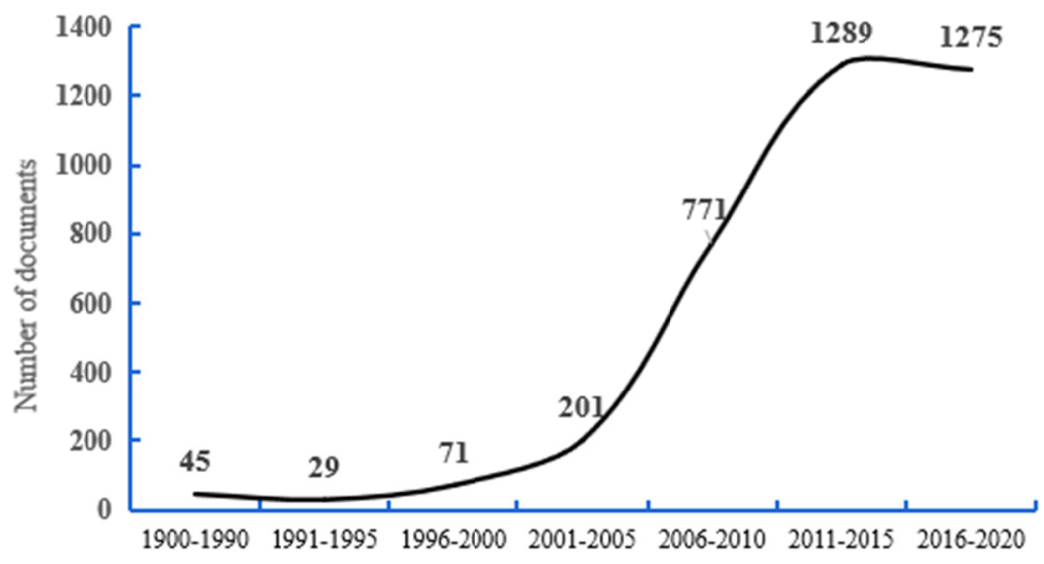

Figure 1. Statistical line chart of "teacher training" related literature collected by CNKI

As can be seen from the figure, the research articles on "teacher training" have been growing rapidly since entering the 21 st century. In the past ten years, there have been 2563 related studies and the research results are quite fruitful. In the retrieval results, there are more frequent entries, such as "teacher training mode", "double qualified teachers", "excellent teachers", "normal students", "primary and secondary school teachers", "teacher training", "teaching reform" and so on. Although the number of literature on "teacher training" is quite a lot, there are not many literature studies on "the cultivation of middle school teachers", especially on the training mode of "middle school biology teachers". It is worth mentioning that there are some similarities between the training mode of biology teachers in middle school and the other teachers, which can be used for reference. However, biology has its unique characteristics, so the cultivation of its normal students should also develop its own unique path under the general training requirements. Moreover, with the development of the times, biology in middle school has put forward new requirements for the cultivation of talents, which is also a hot topic worthy of continuous research.

\subsection{The Current Situation of the Training Mode of Middle School Biology Teachers in Foreign Countries}

Many foreign countries are exploring the effective mode for training middle school biology teachers. Some studies have pointed out that (Chen et al., 2018), some countries and international organizations have reached a consensus to improve the quality of teachers at all stages with the implementation of the excellent teacher training program, so as to support the development of domestic education business. For the cultivation mode of middle school biology teachers, different countries have different focus, but there are also some similarities. 
Each country has their corresponding education laws and policies so as to regulate and guarantee the training plan of teachers. While studying biology, normal students should also cross-study other subjects, such as environmental science and other humanities courses. Besides, the cultivation of biology teachers tends to be highly educated, and the focus of training shifts to postgraduate stage (Liu et al., 2013). With the continuous progress of science and technology, the training modes of biology teachers of secondary school in various countries are adapting to the trend of the era, constantly innovating and developing.

\subsection{The Development Trend of Middle School Biology Teachers' Training Mode}

What kind of middle school biology teachers needs to be trained in the future? How to train them? It should be explored according to the actual situation of the era. However, the future development ideas of various countries have similar trends.

First, the concept of STEAM is in vogue (Wang, 2020). STEAM, firstly proposed by the United States, is a comprehensive education integrating science, technology, engineering, art and mathematics. Biology has multi-level internal relationships with other disciplines. Interdisciplinary education can expand the knowledge of biology teachers of middle school, better grasp the knowledge logic of biology and benefit the comprehensive development of talents.

Second, attention has been paid to the "normal nature" of middle school biology teachers. In terms of the curriculum arrangement of normal university students, the proportion of practical courses in biology teaching is increasing. Some countries have even increased the education years and the teaching practice hours for undergraduate biology normal university students, so as to better exercise their teaching ability. Besides, China is also exploring a holistic and continuous training mode for undergraduate and master of education students (Ministry of Education, 2018). Some colleges are trying to train biology normal students with the mode of " $4+2$ " or " $3+2$ " study years (Tian, 2011).

Third, lifelong learning gets more emphasis. The researches on middle school biology teaching theory should keep up with the pace of the era. The training of biology teachers should pay more attention to the development of their lifelong teaching career and reform the cooperative training mode between middle schools and universities (Pan, 2018). Teachers must take biology teaching as a lifelong pursuit. In this process, teachers should take the initiative to find problems in biology teaching and innovate ways to solve problems with enthusiasm and confidence. More importantly, biology teachers should practice in research, study in reflection and realize their self-development in the long-term teaching.

The reform of the talent training mode of middle school biology teachers is closely related to many factors such as the government and society. However, the most fundamental thing is that colleges and universities should take the main responsibility of biology teaching reform and talent training mode innovation. The cultivation of middle school biology teachers should take "what kind of teachers to train" as the goal guidance and innovate the new reform path of "how to cultivate teachers". Colleges are actively adapting to the development of society and seeking new modes to improve the quality of personnel training, which still needs a long way to go.

\section{Problems in the Training Mode of Middle School Biology Teachers}

The promotion of quality education and the implementation of the new curriculum reform have profound impacts on the teaching in many schools. But there are still some problems in the training mode of biology normal students in some universities.

\subsection{The Educational Concept of Colleges Needs to be Improved}

If the university's education goal is unclear and the corresponding system is not implemented exactly, it will easily lead to the disconnection between the curriculum and teaching setting for the cultivation of biology normal students (Wang, 2009). Some colleges do not respect the subjectivity of students' learning and the teaching method is mainly based on teaching. Such important courses as pedagogy and psychology still choose to teach in large classes. Teachers speak on the podium themselves, while students' listening or not depends on their own consciousness. It is difficult to arouse students' enthusiasm for learning educational theories without teacher-student interaction. Colleges should set up student-oriented educational idea, focus on students' learning, strengthen the ideological construction of biology normal students, innovate ideas and train high-quality and innovative biology teachers in the new era. Today, with the rapid development of the Internet, colleges should also have information-based biology teaching ideas, give full play to the advantages of information technology in and make use of diversified teaching platforms such as massive open online course and micro-courses to combine classroom teaching with online learning. Diversified teaching ways could better arouse students' interest and love in biology teaching. 


\subsection{There are Defects in Teaching Arrangement in Colleges}

1) There is a problem that the curriculum of education focuses on biological professional courses but neglects biological normal courses. The proportion of education and teaching courses and middle school biology teaching practice courses are too small and the training of students' teaching is insufficient (Lu, 2016). There is a lag in curriculum setting in some colleges, the new curriculum standard of biology in middle schools and new biology textbooks need to be considered. The differences between theoretical study and practical operate may make normal students unable to do their best in the future biology teaching.

2) In biology education practice, biology interns have some problems, such as lack of basic skills, lack of teachers' sense of responsibility and mission, maladjustment of mentality, etc. Besides, due to the lack of effective communication and norms, biology teaching practice is out of control and becomes a mere formality, which can't achieve the desired results (Zhao, 2019).

3) Teaching evaluation of biology normal students is quite simple and there is a lack of examination on mental health and communication ability for them. Simple internship reports and grades can't effectively represent students' abilities and are not conducive to students' reflection on their own progress and shortcomings. In a word, normal universities should carefully examine their own weak points and rationally adjust the educational curriculum system of biology normal students to promote them to become more professional.

\subsection{There is an Imbalance in the Development of Schools}

Different colleges have different training modes. Some schools are ahead of the reform of the training mode of middle school biology teachers. For example, in the setting of elective courses, they will provide students with different elective directions, such as development psychology course, blackboard writing training course, biology curriculum standard study course, middle school biology teaching method course, etc. Students can make targeted choices and enrich their knowledge. However, some schools have few or no optional subjects, which is not conducive to the comprehensive development of students.

In addition, in the same school, the level of students is also uneven. Some biology normal students do not have enough knowledge and skills of biology teaching. Their actual teaching ability, class management ability and communication ability can't meet the requirements of middle school. With the increasing number of graduates of biology normal students, the training quality of middle school biology teachers can't meet the needs of employers, which forms a special contradiction between supply and demand. As a result, the employment pressure of biology normal students is gradually increasing (Zhang, 2020).

\section{Thoughts on the Training Mode Reform of Middle School Biology Teachers}

The original training mode of biology normal students can no longer meet the requirements of talent development under the information environment of the new era and the reform has entered the present continuous tense. The necessity and urgency of reform is self-evident, but there is no definite answer to the questions of how to reform and what aspects to start with. More importantly, the reform does not need kinds of rules and regulations. Colleges should follow the general requirements of the Ministry of Education that train a large number of high-quality professional teachers with noble teachers' morality, solid professional foundation, outstanding teaching ability and self-development ability. And on the basis of meeting the actual development of local biology disciplines and respecting students' needs, colleges must reform the training mode of biological normal students. Generally speaking, we can improve the talent training mode of biology teachers in middle school from the following aspects.

\subsection{To Train Middle School Biology Teachers Good at Learning}

In order to cultivate excellent biology normal students, it is far from enough to teach the biological knowledge in class. Students should not only master rich knowledge of education and teaching, but also have independent learning methods, apply them in practice and have a sense of lifelong learning.

1) To impart knowledge in an all-round way. Abundant knowledge and skills are essential for an excellent middle school biology teacher. In addition to general education courses and biological professional courses, students majoring in biological science also need to take courses such as Biology Teaching Theory in Middle School, Biology Curriculum Standards Analysis in Middle School, and get exercise through on-campus probation and teaching biology class in middle schools. Through the systematic study of the knowledge, normal students can gradually establish the role consciousness of biology teachers and master teaching skills from shallow to deep.

With the popularization and application of multimedia technology in teaching, teachers should be able to 
skillfully make and use electronic courseware. Especially during the epidemic this year, biology teachers have to teach online. The use of live broadcast platform and the production of recorded lessons pose new challenges to them. Consequently, biology normal students should keep up with the pace of educational informatization and improve their TPACK ability which is the ability to integrate the subject teaching knowledge and technology. They should also pay more attention to the teaching theory and methods under the information technology environment and realize professional development through accumulation (Kui et al., 2017). In addition, the use of PPT courseware saves some teachers' writing time as it can directly display large text descriptions in biology textbooks to improve the efficiency of biology teaching. However, some biological knowledge such as the model diagram of DNA molecules and the calculation of genetic laws, is better to write by teachers and demonstrate to students bit by bit, which is easier for students to understand and remember than simply showing. Therefore, it is also very important to carry out calligraphy and painting courses to improve teachers' blackboard writing skills and writing ability (Zong et al., 2019).

2) To promote independent learning. Confucius once said, "Those who know are not as good as those who are good, and those who are good are not as good as those who are happy." Biology is a subject full of interest. Students should be good at discovering the fun in biology learning and learn it actively independently.

First, colleges and universities should update their educational concepts to create free and harmonious learning environment for students. It is necessary to build as many kinds of intelligent classrooms as possible. Small class teaching and multi-screen display form a good teaching atmosphere, which is beneficial to the discussion between teachers and students.

Second, lecturers should change the teaching methods appropriately. The lack of learning initiative of normal biology students can't be separated from their own reasons, but it is also related to teachers' traditional teaching methods. It is necessary to strengthen discussions among students and respect students' dominant position. Teachers can extend some biology hot spots to encourage students to actively explore deeper knowledge. In addition, the hybrid biology teaching mode combining "online" and "offline" teaching is helpful to cultivate students' self-directed learning ability and effectively solve the prominent problems of dull and inefficient traditional classroom atmosphere (Zhang et al., 2020). However, when designing online courses, colleges should pay attention to the properly use of teaching platforms, considering from the characteristics of biology and the needs of students. It should not rely too much on online forms, so as not to avoid causing extra burden to students (Kang, 2019).

Third, students can establish learning communities to help each other. Independence study does not mean self-study. Establishing a biology study group can make each other find the spark of wisdom in the collision of thinking. The group can also do practical research on a middle school biology education topic. If there is any difficulty, they can consult information or ask teachers for help. In the process of solving the problem, both the group and the individual can grow up.

3) To pay more attention to the cultivation of practical ability. It is not enough to have theoretical knowledge. Biology normal students need to learn how to carry out biology teaching and have a broad world to play freely. Colleges should adhere to the practice orientation, build a multi-level and multi-platform practical education system and cultivate the core literacy of biology normal students in diversified activities (Li, 2019). It is necessary to invite front-line education researchers and middle school biology teachers with rich teaching experience to give lectures and guidance. Regularly holding some teaching skills competitions like lecture contest, teacher's morality speech contest, etc., can strengthen the skills training of normal students in a situational and open environment (Wang et al., 2017). "The second classroom" teaching training, on the one hand, can make them well prepared psychologically to enter the role of middle school biology teachers in advance. On the other hand, it also broadens the vision of students to improve their enthusiasm and initiative of developing teaching skills, which can lay a foundation for practical biology teaching in secondary schools in the future (Lin et al., 2018).

4) To establish the concept of lifelong learning. Biology normal students should have the consciousness of lifelong learning. First of all, biology is a science, which is continuously inherited and developed on the basis of previous studies. Biology teachers should establish awareness of paying attention to hot topics in biology. Biology knowledge is being updated, biology curriculum standards are developing, biology textbooks need to be replaced, and biology teachers in middle schools should keep pace with the era to learn new knowledge and new ideas in professional fields. After working in the future, they should participate in academic exchanges and improve their teaching level (Wu, 2017). Secondly, the STEAM education concept has become the education trend and new learning forms such as "flip classroom" and "e-book bag" are constantly appearing, which pose 
new challenges to the professional ability of middle school biology teachers. Biology normal students should not stop at their undergraduate studies, but should hone their practice in the future teaching. They should keep advancing towards the goal of becoming an excellent middle school biology teacher.

\subsection{To Train Middle School Biology Teachers with Innovative Spirit}

One of the characteristics of teachers' labor is creativity, which is mainly because the educational objects are special and complex individuals. Teachers cannot treat different students with similar templates. Especially in today's era of advocating the protection of students' personality, modern middle school biology teachers should give full play to their creativity to make biology classes colorful to cultivate more energetic students. Accordingly, in terms of teacher training, colleges should change the training system of biology teachers and reform the previous mode that focused on imparting professional theoretical knowledge. The cultivation mode of biology teachers should also focus on stimulating creative thinking, learning innovative skills, and forming innovative personality (Guo, 2019).

\section{1) To cultivate creative thinking}

Creative thinking is the core of creativity. Cultivating the creative thinking of biology students will help them grow into creative teachers. It is necessary to create a biology teaching environment conducive to the development of personality. Reasonable arrangement of inquiry teaching and democratic classroom atmosphere can influence students subtly and encourage them to express their views freely. It should be noted that in inquiry teaching, teachers play a guiding and supporting role and should reasonably control the conversation with students to train the initiative and creativity of them (Hiltunen et al., 2020).

In addition, creative courses can be set up to cultivate divergent thinking. The opening teaching content can train students' hands-on and brain-thinking ability by appropriately adding biology inquiry experiments in the biology teaching. In the training of biology teaching skills, students should be guided to use different methods to introduce, ask questions and design teaching processes to experience the application of various skills. Students can also fly their imagination and make biological teaching aids with common materials in life, such as making paramecium model with shoe mat and making cell model with hollowed grapefruit shell. It is beneficial to develop students' creative thinking by viewing problems from different angles.

2) To master innovative teaching methods

Firstly, to carry out creative teaching activities, it is essential to master a lot of knowledge as the foundation, not only the biological professional theory, but also the principles of various phenomena in society and some interdisciplinary knowledge. There is enough knowledge to give full play to the space of imagination. Secondly, students should learn creative methods and consciously train them with various methods, such as brainstorming, divergent thinking, inference hypothesis, etc. Teachers should learn to use mind maps to clarify the context logic of biology. Finally, creative skills should be used flexibly. When doing teaching design in practice, biology normal students should not copy reference books and online resources, but deal with them flexibly according to students' actual situation and their own abilities. For example, in the middle school classroom teaching of "organic matter produced by photosynthesis of green plants", a teacher made different teaching arrangements for the classic experimental of J. von Sachs (Zhu, 2011). She adopted reverse thinking, first assuming that starch is produced by photosynthesis of leaves. And the problems that how to detect the beginning, how to remove chlorophyll and how to verify the role of light, will inspire students to think and deepen their understanding in the discussion.

\section{3) To shape innovative personality}

Innovative personality can't be formed overnight. Biology teachers of middle school should make sustained professional development plans. They should use creative techniques flexibly on the basis of creative thinking and form biological science literacy in life (Eda et al., 2018). First, it is important to keep curiosity and insight into life. Curiosity will stimulate the desire to explore. As biology is closely related to the life and society, keeping curiosity can help students find different biological beauty in ordinary life. Second, biology teachers should keep a good attitude, know themselves correctly and be good at adjusting their mentality. Teaching work day after day may produce a sense of professional slackness. Teachers should take biology teaching as their own interest and keep creative enthusiasm for teaching to enhance their sense of professional accomplishment (Yao, 2020). Third, teachers should think critically and view the hot topics of biology and the new progress of education and teaching from multiple angles. By internalizing them into biology teaching, teachers will form their own teaching characteristics. 


\subsection{To Train Middle School Biology Teachers with Reflective Spirit}

\section{1) To reflect after class}

"Learning without thinking is useless". Many courses in biology are complicated and there are many contents to be learned in each class. If students don't review after class, they can't master well the context and key points of knowledge. They should find more internet resources to expand their knowledge after class. Of course, discussing with classmates in $\mathrm{QQ}$ or WeChat group to solve difficult problems will deepen their understanding of knowledge points. Students should not only review what they have learned, but also learn to adjust their learning mentality (Jim, 2019). Students should enhance their self-discipline, self-confidence and self-efficacy in self-assessment to maintain their enthusiasm and confidence in learning.

\section{2) To reflect on practice}

The reflection after practice is much more important. It is necessary to find and solve problems in the practical teaching of biology in middle schools. Through cognition, practice, re-cognition and re-practice, the teaching level can rise step by step and achieve a virtuous circle. Biology normal students should ask themselves three questions after each teaching and speaking: what advantages do I have compared with other students? What are my shortcomings? What actions should be taken to improve my biology teaching skills? Students should be good at reflection, learn strengths from each other and put them into action to make more progress next time.

At the same time, normal colleges should standardize the management system of middle schools, cooperate with them to implement appropriate teaching arrangements, and conduct professional assessment on the learning situation and teaching skills of students (Yin, 2019). Students' abilities cannot be judged only by a few numbers on transcripts. The multidimensional evaluation like the judge from teachers, classmates, ego and society, and the multiform evaluation methods like evaluation scale, electronic portfolio and student works collection, can be used properly to diversify teaching evaluation and make a comprehensive analysis for students' actual biological teaching ability, which is conducive to students' better understanding of themselves and development of their personality.

\section{3) To reflect in research}

Teachers should also be researchers. The cultivation of middle school biology teachers should pay equal attention to both pedagogy and academic research. In the teaching practice of normal students, biology teachers in middle schools teach students biological knowledge, while students feed back various educational materials. Teachers should take the initiative to find out the problems existing in the actual teaching and carry out research on biological teaching topics. Task research can help middle school biology teachers master the essence of teaching efficiently and accumulate rich teaching experience and wisdom (Zhang et al., 2020). In the research reflection, the middle school biology teachers will establish their own unique personality charm, edify students imperceptibly in the teaching and form their own teaching art.

In the undergraduate stage, normal students can set up a biology study group to explore the research on a certain middle school biology teaching topic, and consciously reflect on their own practice to commit to solving practical teaching problems. In addition, while reading classic education monographs, biology normal students can also take into account some excellent works of modern educators, such as 40 Years Old, Start to Learn to Do Education, which has many educational essays, and Understanding Teaching and Cases of Biology Concepts in Senior High School, which is in line with the actual biology teaching in Beijing No.19 middle school. These new works can not only help students broaden their horizons and learn from the teaching experience of excellent middle school biology teachers, but also inspire them to record their own educational mental process. Through education writing, they can grow into an excellent middle school biology educator during the continual process of reflection.

\section{Conclusion}

The traditional talents training mode of middle school biology teachers has been unable to meet the requirements of the development of talents. The new mode of personnel training is still in constant exploration. Countries all over the world are looking for the new path. Normal colleges and universities in our country should undertake the important task of mode innovation. In view of the problems in the traditional training mode of biology teachers in middle school, they should take a series of measures and combine the characteristics of biology to comprehensively improve the new ideas and methods of biological teacher training. In the aspect of learning, colleges should impart knowledge comprehensively, advocate independent learning methods, attach importance to the cultivation of practical ability and let biology normal students establish the concept of lifelong learning. In the aspect of innovation, it is necessary to cultivate students' creative thinking and teach innovative teaching 
methods to shape students' innovative personality. As for the reflection, colleges and universities should not only pay attention to the after-school reflection and practical reflection of biology normal students, but also help them to reflect in the research, so as to realize the professional development and career promotion of middle school biology teachers in the future.

Although it is necessary to reform the personnel training mode of biology teachers in middle school with normal universities as the leading factor, it is not possible to "run only by higher education institutions". The reform also requires the government to do a good job in top-level design and secondary schools to improve the post service training. The three parties should work together to cultivate biology teachers who are good at learning and have innovative and reflective spirits. More importantly, our country should strengthen the communication and exchange with the international community, and learn the beneficial experience to train the high-quality and innovative middle school biology teachers with interdisciplinary knowledge and ability in the future.

There may be difficulties in the process of reform. However, colleges will face and solve them with matchless courage and determination, and strive to form a unique local advantage and the Chinese characteristics of the cultivation mode of middle school biology teachers! Biology normal students should also constantly improve their teaching ability and level to promote the steady improvement of biology teaching quality in middle school, greeting the promising life of biology teaching in middle schools with a high-spirited attitude. Acknowledgments

This work was financially supported by Postgraduate Education Reform Project of Henan Province (2019SJGLX088Y), The Training Plan of Young Backbone Teachers in Colleges and Universities of Henan Province (2019GGJS162), Special Research Project of Teacher Education Linkage Development Community in Southern Henan (2019-GTTYB-01), Research Project of Teacher Education Curriculum Revolution of XYNU (2019-JSJYYJ-10), Research and Practice Project of Education and Teaching Reform of XYNU (2019032) and Innovative Training Program for University Students in Henan Province (201910477004).

\section{References}

Chen, D. B., \& Yang, X. X. (2018). International experience and inspiration of excellent teacher training. Contemporary Teacher Education, 11(3), 67-72, 78.

Cui, H., \& Zheng, X. H. (2016). New Concept Biology Teaching theory. Beijing: Peking University Press.

Eda, E. K., William, W. C., Nihal, D., Serhat, I., Gultekin, C., \& Yalcin, Y. (2018). Improving science teachers' nature of science views through an innovative continuing professional development program. International Journal of STEM Education, 5(1), 1-10. https://doi.org/10.1186/s40594-018-0125-4

Guo, W. (2019). Building innovative teacher training and growth model. Education, 41, 66-67.

Han, X. P., \& Li, S. (2020). Value implication of Xi Jinping's important discourse on teacher occupation in the New Era. Journal of Fujian Normal University (Philosophy and Social Sciences edition), 1, 9-16.

Hiltunen, K. K. (2020). Biology student teachers' dialogic talk in inquiry-based instruction. Journal of Biological Education, 54(3), 300-314. https://doi.org/10.1080/00219266.2019.1575264

Jim, T. (2019). The Alphacrucis College clinical teaching model: An evaluation. International Journal of Christianity \& Education, 23(3), 327-348. https://doi.org/10.1177/2056997119865565

Kang, S. L. (2019). Application research of blended teaching mode in the cultivation of excellent teachers. Science and Technology Vision, 26, 82-84. https://doi.org/10.19694/j.cnki.issn2095-2457.2019.26.038

Kui, X., Min, K. K., Cheng, S. L., \& Nicole, C. L. (2017). Teacher professional development through digital content evaluation. Educational Technology Research and Development, 65(4), 1067-1103. https://doi.org/10.1007/s11423-017-9519-0

Li, J. K., \& Yan, N. N. (2020). The construction of diversified teacher education talent training mode in local colleges and universities. Teaching and Educating (Higher Education Forum), 15, 29-31.

Li, M. (2019). Research on teacher vocational skill training model based on core literacy. Journal of Zhongzhou University, 36(5), 105-108. https://doi.org/10.13783/j.cnki.cn41-1275/g4.2019.05.020

Lin, X. P., Luo, F., \& Zhou, F. F. (2018). Reform and practice of teaching skills training for biology normal college students in middle schools. Education and Teaching Forum, 51, 89-91.

Liu, Y. L., Yang, S. P., Zhang, R. K., \& Hong, Y. J. (2013). The enlightenment of teacher education training mode and curriculum in the United States and Britain. Journal of Education College of the Corps, 23(1), $35-38,43$. 
Lu, Y. F., Xia, M., \& Yang, J. W. (2016). Discussion on the cultivation model of normal university students majoring in biology under the new situation-A case study of local normal universities. Educational Observation (first half), 5(3), 52-53. https://doi.org/10.16070/j.cnki.cn45-1388/g4s.2016.05.022

Ministry of Education of the People's Republic of China. (2018). Ministry of Education's comments on the implementation of The Excellent Teacher Training Scheme 2.0. Chongqing and the World, 22, 16-18.

Ministry of Education of the People's Republic of China. (2020). Curriculum Standards for General Senior High School Biology (2017 edition, 2020 revision). Beijing: People's Education Press.

Pan, Q. (2018). Experience and enlightenment of international teacher education. China Adult Education, 21, $113-115$.

Tian, B. (2001). Reflections on the quality training of students majoring in biology education. Training and Research (Journal of Hubei Institute of Education), 5, 62-63.

Wang, H. Y., Sun, Y. D., Liu, Y. F., Yan, M. L., \& Xiang, Y. C. (2017). Docking and reconstruction: exploration of the training mode and system of "Double Strength" practical Ability for biology normal university students. Contemporary Educational Theory and Practice, 9(10), 56-60. https://doi.org/10.13582/j.cnki.1674-5884.2017.10.015

Wang, W. L. (2009). The key to improving the quality of education: Deepening the reform of talent training mode. Educational Research, 30(12), 30-34.

Wang, W. Q., Ding, J., \& Li, J. X. (2020). Analysis of the current situation of STEAM Education teacher Training in China in recent ten years. Modernization of Education, 7(24), 42-47. https://doi.org/10.16541/j.cnki.2095-8420.2020.24.012

$\mathrm{Wu}$, R. (2017). Training model of normal biology students. Education and Teaching Forum, 4, 48-49.

Yao, F. M. (2020). Innovative training mode and achievement of teachers' career ideal. Xuzhou Weekly, 14, 191-192. https://doi.org/10.16657/j.cnki.issn1673-9132.2020.14.094

Yin, W. D. (2019). Relevant thoughts on teaching practice guidance for normal university students. Policy \& Scientific Consult, 12, 13.

Zeng, Y. Y. (2019). Research on pre-service outstanding teacher training program in the United States. Master dissertation. Hunan: Hunan University of Science and Technology. Retrieved from https://kns.cnki.net/KCMS/detail/detail.aspx?dbname=CMFD202001\&filename=1020609818.nh

Zhang, D. J., Gao, T. T., \& Wu, Y. J. (2020). Reform and innovation of students' educational practice mode in normal colleges and universities-A case study of biological science major of Henan Normal University. Education and Teaching Forum, 11, 43-44.

Zhang, Q. F., Lu, J., Yang, E. H., Chen, Q. P., \& Liao, D. Q. (2020). Research and practice of student-centered blended teaching. Light Industry Technology, 36(8), 164-165, 167.

Zhang, Y. (2020). A Brief analysis on the cultivation of the employability of biology normal students. Labor Security World, 12, 14.

Zhao, J. H. (2019). Reflections on the improvement of educational practice management system in the context of excellent teacher training. Journal of Hefei Normal University, 37(5), 114-117.

Zhu, Z. W. (2011). Teaching Design depends on teaching innovation. Bulletin of Biology, 46(12), 16-17.

Zong, X. C., Jin, Z. M., Cai, H., Zong, C. H., Du, D. B., \& Deng, M. S. (2019). Research on the meritocratic training model of biological science teachers. Journal of Mudanjiang Normal University (Natural Science edition), 1, 71-72, 76. https://doi.org/10.13815/j.cnki.jmtc(ns).2019.01.018

\section{Copyrights}

Copyright for this article is retained by the author, with first publication rights granted to the journal.

This is an open-access article distributed under the terms and conditions of the Creative Commons Attribution license (http://creativecommons.org/licenses/by/4.0/). 